UDC 378.147:656.2-051

DOI https://doi.org/10.31470/2415-3729-2020-12-109-127

\title{
Structural and Functional Model of the System of the Future Railway Transport Specialists Professional Education in the Conditions of Lifelong Education
}

\section{Natalia Malanyuk}

Doctor of Philosophy in Pedagogy (Ph.D),

Cycle Commission of General Education Disciplines,

Kyiv College of Transport Infrastructure

$\triangle 16$, Ya. Homova str., Kyiv, Ukraine, 02000

E-mail: malanyuk.nat@gmail.com

ORCID: https://orcid.org/0000-0002-4321-0900

Date of receipt of the article: September 28, 2020 Article accepted for publication: November 22, 2020

\section{Структурно-функціональна модель системи професійної підготовки майбутніх фахівців залізничного транспорту в умовах неперервної освіти}

\section{Наталія Михайлівна Маланюк}

кандидат педагогічних наук, циклова комісія загальноосвітніх дисциплін, Київський коледж транспортної інфраструктури $\checkmark$ провул. Я. Хомова, 16, м. Київ, Україна, 02000

Дата надходження статті: 28 вересня 2020 p. Стаття прийнята до друку: 22 листопада 2020 р.

\section{Abstract}

The research is an attempt to substantiate the system of professional education of future railway transport specialists in 
the conditions of lifelong education as the unity of such blocks as purposeful, informatory, operational and effective. The components of each block are analyzed, as well as the relationships between them. The essence and analysis of key characteristics of the definition of «pedagogical system» are revealed. The professional education of future railway transport specialists must meet the demands of society, as well as reflect the level of development of science and technology. Future railway transport specialists must have professional competence, which is considered to be crucial quality of specialist in the context of European integration processes, labor market mobility and growing demands of employers. The system-creating factor is the goal, that is the formation of professional competence of future railway transport specialists in the system «collegeuniversity».

The research purpose is to substantiate and build the structural and functional model of the system of the future railway transport specialists professional education in the conditions of lifelong education. The research methods are analysis of psychological and pedagogical literature on research problems, pedagogical modeling, comparative analysis, systematization and generalization of results.

The results. Building an author's system of professional education for future railway transport specialists should be an attempt to improve the traditional system of vocational education. Such system should be based on humanistic principles, according to which each individual is of the greatest value, along with its individual characteristics, inclinations and abilities. The key methodological approaches of professional education system of future railway transport specialists should be personality-oriented, activity-oriented and competence-forming. The key principles of building the system are continuity, professional orientation, system and consistency, continuity of education, «education for the future».

Conclusions. To study the system of professional education of future railway transport specialists, a structural-functional 
model of such a system has been built, which reflects the functional connections between the structural components of the system. The development of the model makes it possible to search for ways to improve the system of professional education of future specialists in this field. The introduction of professional education system of future railway transport specialists in the educational process will increase the efficiency of the process of training future specialists at different stages of higher education.

Key words: structural and functional model, professional education, professional education system, lifelong education, railway transport specialists.

\section{References}

1. Aleksandrov, G.N. (2000). Pedagogicheskie sistemy, pedagogicheskie processy $\mathrm{i}$ pedagogicheskie tehnologii $\mathrm{V}$ sovremennom pedagogicheskom znanii [Pedagogical systems, pedagogical processes and pedagogical technologies in modern pedagogical knowledge]. Obrazovatel'nye tehnologii $i$ obshhestvo - Educational Tecnology\&Society, 3(2), 134-149 [in Russian].

2. Bezrukova, V.S. (1999). Pedagogika. Proektivnaja pedagogika [Pedagogy. Projective pedagogy]. Ekaterinburg: Delovaja kniga [in Russian].

3. Bespal'ko, V.P. (1977). Osnovy teorii pedagogicheskih sistem [Foundations of the theory of pedagogical systems]. Voronezh [in Russian].

4. Hulai, O.I. (2013). Metodychni osnovy formuvannia fundamentalnoi skladovoi profesiinoi kompetentnosti fakhivtsiv budivelnoho profiliu: monohrafiia [Methodical bases of formation of a fundamental component of professional competence of specialists of a construction profile: monograph]. In L.M. Romanyshynoi (Ed.). Lutck [in Ukrainian].

5. Dmytrenko, T.O.\&Yaresko, K.V. (2011). Kryterialni kharakterystyky pedahohichnoi systemy yak pidgruntia rozrobky tekhnolohii doslidzhennia skladnoho obiekta [Criteria characteristics of the pedagogical system as a basis for the 
development of technology for the study of a complex object]. Bulletin of the Luhansk National University un-tu them. T. Shevchenko, 21 (232), part II, 84-90 [in Ukrainian].

6. Iezhova, O.V. (2014). Klasyfikatsiia modelei v pedahohichnykh doslidzhenniakh. [Classification of models in pedagogical research]. Proceedings. Series: Problems of methods of physical-mathematical and technological education, 2(5), 202207 [in Ukrainian].

7. Zhyzhko, T.A. (2005). Pedahohichna systema odyn iz chynnykiv vprovadzhennia idei intensyfikatsii u profesiinii pidhotovtsi maibutnikh fakhivtsiv. [The pedagogical system is one of the factors of introduction of the idea of intensification in professional training of future specialists]. Scientific journal of NPU named after M. P. Drahomanov. Series 11. Sociology. Social work. Social pedagogy. Management, 3, 144-151 [in Ukrainian]

8. Zabolockij, V.P., Ovodenko, A.A.\&Stepanov, A.G. (2001). Matematicheskoe modelirovanie $v$ upravlenii [Mathematical modeling in management]. Saint-Petersburg: SPb GUAP [in Russian].

9. Zobnin, B. B. (2001). Modelirovanie sistem: konspekt lekcij. [Systems modeling: lecture notes]. Ekaterinburg: Izd-vo UGGGA [in Russian].

10. Kuz'mina, N.V. (2002). Predmet akmeologii [The subject of acmeology]. Saint-Petersburg: Politehnika. [in Russian].

11. Kuzminskyi, A. I. (2006). Pedahohika u zapytanniakh $i$ vidpovidiakh: navch. posibn. [Pedagogy in questions and answers]. Kyiv : Znannia. [in Ukrainian].

12. Nychkalo, N. H. (1995). Profesiino-tekhnichnii osviti derzhavnu polityku ta naukovo-pedahohichne zabezpechennia [Vocational and technical education - state policy and scientific and pedagogical support]. Novi tekhnolohii navchannia - New learning technologies, 15, 9-18 [in Ukrainian].

13. Orshanskyi, L. V. (2006). Profesiina pedahohika: navch. posibn. dlia studentiv spetsialnosti «Profesiine navchannia» [Professional pedagogy: a textbook for students majoring in «Professional Education»]. Kyiv [in Ukrainian]. 
14. Pobirchenko, N. S. (2010). Formuvannia neperervnoi pedahohichnoi osvity yak systemy z pohliadu istorychnykh peretvoren (II polovyna XIX — pochatok XX st.). [Formation of continuous pedagogical education as a system in terms of historical transformations]. Pedahohika ta psykholohiya Pedagogy and psychology, 2 (67), 68-78 [in Ukrainian].

15. Shtoff, V. A. (1966). Modelirovanie v filosofii [Modeling in philosophy]. Leningrad: Nauka [in Russian].

\section{Вступ}

Інтеграція України в Свропейський економічний та освітній простір, міжнародний розподіл праці, необхідність реформування системи залізничного транспорту відповідно до умов світового ринку висувають нові, більш високі вимоги до системи підготовки молодших бакалаврів (бакалаврів) залізничного транспорту, оскільки передумовою стабільного розвитку держави $є$ компетентні конкуренто спроможні фахівці. На сучасному етапі спостерігається збільшення навчальної інформації, стрімкі зміни в технічному оснащенні діяльності. Все вище описане вимагає необхідності докорінних змін і оновлення змісту навчальних дисциплін та розробки нових програм, зменшення термінів навчання, підвищення якості підготовки фахових молодших бакалаврів залізничного транспорту - це ті актуальні проблеми, які постають сьогодні перед фаховою передвищою освітою України, а також перед закладами, в яких вона реалізовується.

Галузь залізничного транспорту $є$ складовою економічної системи України, тому іiі розвиток та ефективне функціонування важливе для економіки України. Болонська конвенція, а також імплементація української залізниці в європейську, з одного боку, вимагають від майбутніх фахівців залізничного транспорту володіння професійною компетентністю та готовністю до професійної діяльності, здатності до самовдосконалення та саморозвитку, готовності до підвищення рівня кваліфікації тощо, а з іншого боку - 
пропонують нові можливості: мобільність кадрів, європейські стандарти освіти та оплати праці, відповідність освіти запитам суспільства в цілому та кожного індивіда зокрема.

Проте традиційна система професійної підготовки майбутніх фахівців залізничного транспорту виявилася не готовою до сучасних викликів суспільства, а також європейського співтовариства після ратифікації угод з СС та підписання відповідних директив у сфері залізничного транспорту. Тому виникла нагальна потреба пошуків шляхів вдосконалення та модернізації традиційної системи професійної підготовки майбутніх фахівців залізничного транспорту.

Проблемам аналізу педагогічних систем присвячено праці таких науковців, як О. Диса, I. Каньковського, Н. Кузьміної, Л. Оршанського та інших. У своїх працях автори по-різному розкривають сутність дефініції «педагогічна система» та вказують на конкретні іiі характеристики. Проблемам педагогічного моделювання присвячено праці Б. Зобніна, Н. Брюханової, Н. Корольової, В. Краєвського та інших. У дослідженнях цих авторів розглянуто загальну проблему педагогічного моделювання.

Проведений аналіз наукових досліджень 3 проблем дослідження показав, що питання побудови системи професійної підготовки майбутніх фахівців залізничного транспорту, а також структурно-функціональної моделі цієї системи залишилися поза увагою науковців. Тому актуальною $є$ проблема побудови системи професійної підготовки майбутніх фахівців залізничного транспорту, враховуючи євроінтеграційні вимоги та стрімкий науковотехнічний прогрес. Враховуючи вище викладене, метою cmammi $\epsilon$ обгрунтування та побудова структурнофункціональної моделі системи професійної підготовки майбутніх фахівців залізничного транспорту в умовах неперервної освіти. 


\section{Матеріал і методи дослідження}

У ході здійснення дослідницької діяльності нами було здійснено аналіз психолого-педагогічної літератури 3 проблем дослідження. На етапі побудови моделі системи професійної підготовки майбутніх фахівців залізничного транспорту було застосовано метод педагогічного моделювання. На завершальному етапі було використано методи порівняльного аналізу, систематизування та узагальнення результатів дослідження.

\section{Результати та їх обговорення}

Науковці наголошують, що підготовка майбутніх фахівців - здобувачів вищої освіти є багатогранною системою, яка виконує низку функцій: продукування знань, засвоєння знань, поширення знань, формування в студента усвідомлення необхідності навчання протягом життя (Кузьмінський, 2006). Тому щоб дослідити та охарактеризувати професійну підготовку майбутніх фахівців залізничного транспорту в умовах неперервності освіти нами було здійснено аналіз дефініцій «педагогічна система» та «модель» 3 метою подальшого застосування до педагогічного моделювання системи професійної підготовки майбутніх фахівців залізничного транспорту.

Система - це органічна цілісність складових, які взаємодіють між собою за допомогою певних зв'язків, при чому ця цілісність наділена новими властивостями, якими не володіють окремо взяті іiі системи. Система, яка стосується педагогічних явищ чи процесів, називається педагогічною системою.

У таблиці 1 подано трактування терміну педагогічна система різними науковцями. 
Таблиия 1

\section{Визначення сутності дефініції «педагогічна система»}

\begin{tabular}{|c|c|}
\hline Сутність «педагогічної системи» & Автор \\
\hline $\begin{array}{c}\text { «Динамічно-функціональний комплекс діалектично } \\
\text { пов'язаних між собою компонентів» }\end{array}$ & $\begin{array}{c}\text { T. Жижко } \\
\text { (Жижко, 2005) }\end{array}$ \\
\hline $\begin{array}{c}\text { «Підсистема освітньої системи»; «сукупність } \\
\text { взаємопов'язаних засобів, методів і процесів з метою впливу } \\
\text { на формування особистості» }\end{array}$ & $\begin{array}{c}\text { В. Беспалько } \\
\text { (Беспалько, 1977) }\end{array}$ \\
\hline $\begin{array}{c}\text { «Наявність взаємозв'язків та взаємовпливів між } \\
\text { компонентами» }\end{array}$ & $\begin{array}{c}\text { Г. Александров } \\
\text { (Александров, 2000) }\end{array}$ \\
\hline $\begin{array}{c}\text { «Єдність складових: мета, освітня інформація, способи } \\
\text { педагогічної комунікації, студент, викладач та взаємозв’язки } \\
\text { між ними» }\end{array}$ & $\begin{array}{c}\text { Л. Оршанський } \\
\text { (Оршанський, 2006) }\end{array}$ \\
\hline $\begin{array}{c}\text { «Множина взаємопов’язаних структурних і функціональних } \\
\text { компонентів, підпорядкованих цілям освіти, виховання та } \\
\text { навчання підростаючого покоління та дорослих людей» }\end{array}$ & $\begin{array}{c}\text { Н. Кузьміна } \\
\text { (Кузьміна, 1980) }\end{array}$ \\
\hline
\end{tabular}

Дослідниця В. Безрукова наголошує, що педагогічна система повинна володіти низкою загальних характеристик: цілісність, ієрархічність, структурність, наявність провідної ідеї, зв'язок із зовнішнім середовищем, здатність до саморозвитку (Безрукова, 1999).

Науковець Т. Дмитренко вказує на такі обов'язкові властивості педагогічних систем, як інтегративність, рефлексивність, технологічність. Аналізуючи педагогічну систему, авторка робить висновки: для дослідження педагогічних систем застосовують парадигму управління; дослідження статики та динаміки педагогічної системи та процесів у ній відбувається шляхом застосування наукових підходів до неї; прияє зв'язку педагогічної теорії 3 практикою; актуалізує питання інтеграції системних рівнів (Дмитренко, 2011: 84-90).

Вивчаючи професійну підготовку майбутніх фахівців залізничного транспорту в умовах неперервності освіти, нами було побудовано систему такої професійної підготовки, яка відповідала таким умовам:

1. Підгрунтям побудованої системи $\epsilon$ науково-теоретичні засади професійної освіти (досвід, сучасні тенденції тощо).

2. Чітка логічна структура (наявність горизонтальних та вертикальних зв'язків між компонентами). 
3. Застосування інноваційних методів, технологій та підходів.

Для дослідження процесу чи явища в педагогічній науці застосовують педагогічне моделювання, яке дозволяє, вивчаючи модель процесу (чи явища), зробити висновок про сам процес (чи явище).

Науковець В. Штофф подає таке тлумачення дефініції «модель»: «уявлена або матеріально втілена система, яка, здійснюючи відтворення об'єкта дослідження, здатна його замінити так, що вивчення моделі дасть нам нову інформацію про об'єкт дослідження» (Штофф, 1966:19).

Дослідниця О. Сжова подає класифікацію моделей в педагогічних дослідження (рис.1).

Науковець Н. Побірченко вважає, що для дослідження взаємовпливів факторів освітнього процесу створюється модель, що розглядає освітній процес як систему, «компонентами якої є різні аспекти цілісного процесу» (дидактичний, гносеологічний, психологічний, кібернетичний, організаційний) (Побірченко, 2010: 275). Вчений Б. Зобнін наголошує, що процес моделювання являє собою послідовність таких дій: - входження в процес, вибір методологічних основ, якісний опис предмета моделювання; - формулювання задач моделювання; конструювання моделі; - дослідження моделі на валіднісь; включення моделі в педагогічний експеримент; - змістова інтерпретація одержаних результатів (Зобнін, 2001).

Дослідниця О. Гулай пропонує розглядати педагогічну систему як сукупність конкретних елементів (блоків), «кожен 3 яких володіє інтегральними властивостями та які утворюють між собою стійку єдність щодо організації педагогічного процесу формування професійної компетентності майбутніх фахівців будівельного профілю в умовах неперервної освіти» (Гулай,2013: 181-190). 


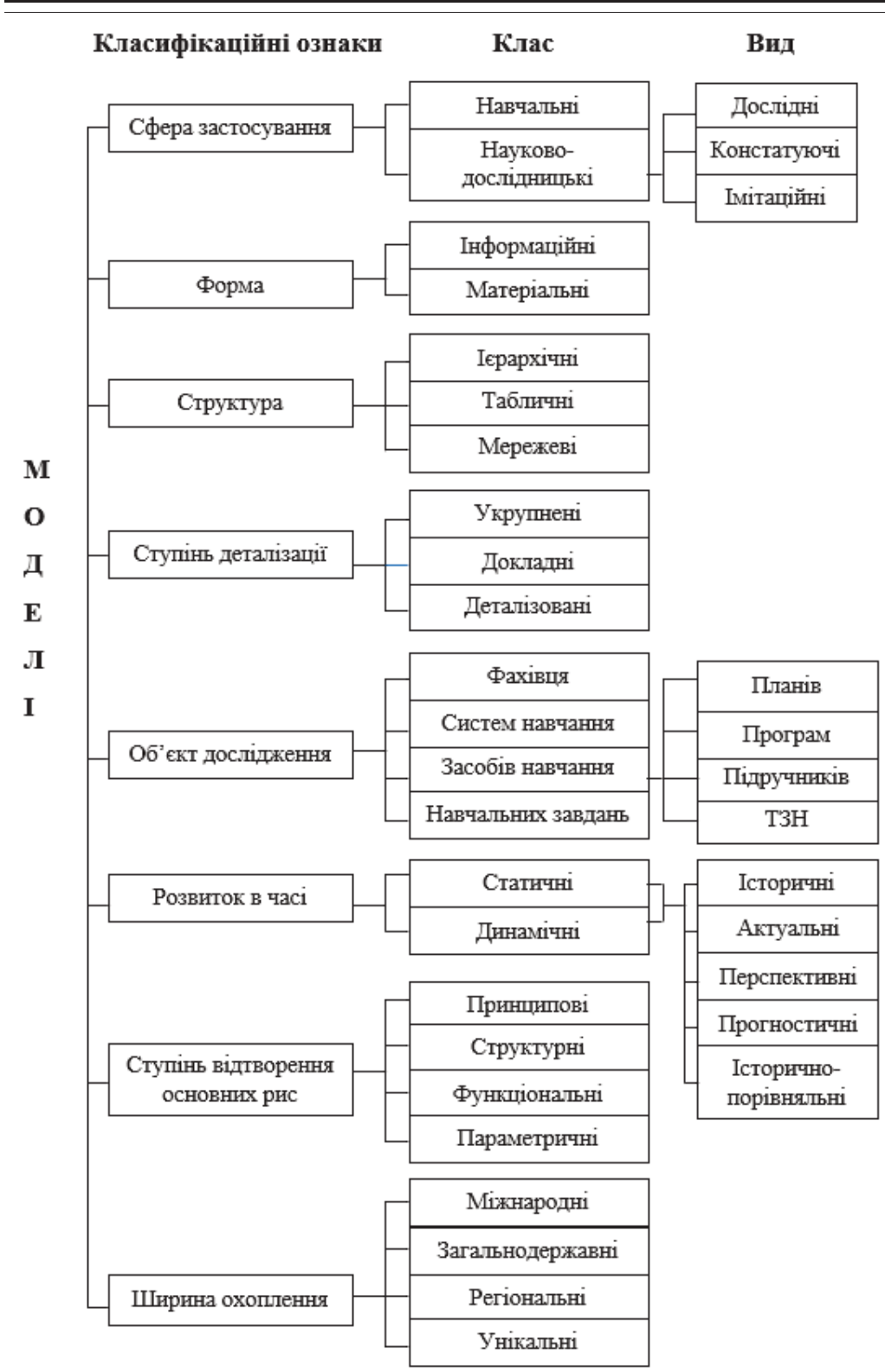

Рис. 1. Класифікація моделей в педагогічних дослідженнях (Сжова, 2016). 
Підгрунтям нашого дослідження були ідеї академіка Н. Ничкало стосовно доцільності моделювання педагогічної системи, поклавши в основу моделювання єдність мети, завдань, видів діяльності, форм організації діяльності, а також визначених наперед критеріїв функціонування системи (Ничкало, 1995).

Побудована нами система професійної підготовки майбутніх фахівців залізничного транспорту в системі неперервної освіти є відтворенням формувальної складової процесу формування професійної компетентності та готовності до професійної діяльності в майбутніх фахівців залізничного транспорту. Така система повинна базуватися на гуманістичних засадах, за яких кожна особистість є найбільшою цінністю разом 3 iï індивідуальними особливостями, задатками та здібностями. Ключовими методологічними підходами системи професійної підготовки майбутніх фахівців залізничного транспорту мають стати особистісно-орієнтований, діяльнісний та компетентнісний. Ключовими принципами побудови системи є наступності, професійної спрямованості, системності та послідовності, неперервності освіти, «освіта для майбутнього». Ця система містить в собі такі блоки: цільовий, змістовий, операційний, результативний і блок педагогічних умов. Цільовий блок. Мета: формування професійної компетентності та готовності до професійної діяльності майбутні фахівців залізничного транспорту. Ціль освітньої діяльності - сприяти формуванню професійної компетентності майбутніх фахівців як єдність таких складових: знання, вміння, досвід, потреба здобувати нові знання в залежності від запитів професійної діяльності. Змістовий блок. Процес формування професійної компетентності та готовності до професійної діяльності майбутніх фахівців залізничного транспорту на кожному етапі ступеневого навчання мають конкретне змістове наповнення. Державні освітні стандарти, ОКХ і ОПП спеціальностей. Змістове наповнення освітнього процесу 
визначається також вимогами ринку праці та соціальним замовленням. Операційний блок. Цей блок являє собою опис організації професійної підготовки майбутніх фахівців, враховуючи всі ㄲï складові. Результативний блок. У ході дослідження нами виокремлено такі компоненти готовності майбутніх фахівців залізничного транспорту до професійної діяльності: когнітивний, ціннісно-мотиваційний, рефлексивний та операційно-діяльнісний. Також було встановлено такі рівні їх сформованості: початковий, середній, достатній, високий.

Модель педагогічної системи професійної підготовки майбутніх фахівців залізничного транспорту в умовах неперервності освіти будемо будувати, враховуючи базову тріаду: професійна компетентність - фундаментальна підготовка - креативна акмеологія (Гулай, 2013).

У нашому дослідженні було побудовано структурнофункціональну модель системи професійної підготовки майбутніх фахівців залізничного транспорту, опираючись на такі якості структурних та функціональних моделей: структурні моделі дають можливість скласти загальне враження про форму, кількість найбільш істотних компонентів системи, а також взаємозв'язків між ними; функціональні моделі дозволяють здійснювати дослідження особливостей функціонування системи відповідно до іiі призначення (Заболоцкий, Оводенко\& Степанов, 2001). Структурно-функціональна модель системи професійної підготовки майбутніх фахівців залізничного транспорту зображена на рис.2.

Розроблена структурно-функціональна модель педагогічної системи є відтворенням авторського бачення концепції професійної підготовки майбутніх фахівців залізничного транспорту в умовах неперервності освіти. Розробка моделі створює передумови для пошуку та розробки оптимальних шляхів удосконалення традиційної системи професійної підготовки фахівців залізничного транспорту. 


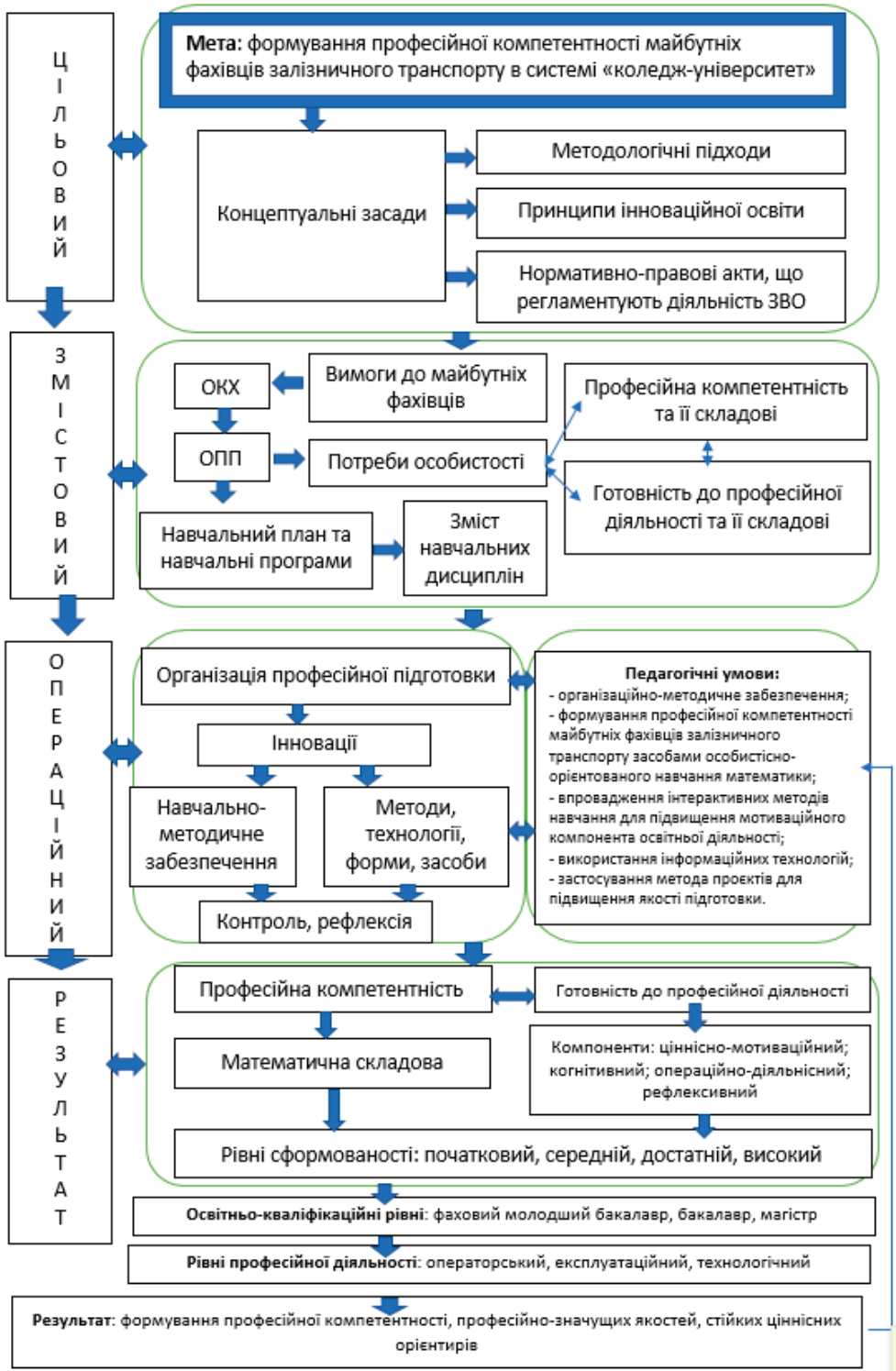

Рис. 2. Структурно-функціональна модель системи професійної підготовки майбутніх фахівців залізничного транспорту в неперервній освіті 


\section{Висновки}

Реалізація структурно-функціональної моделі системи професійної підготовки майбутніх фахівців залізничного транспорту в умовах неперервної освіти сприятиме підвищенню ефективності підготовки майбутніх фахівців на різних рівнях ступеневої професійної освіти: фаховий молодший бакалавр - бакалавр - магістр шляхом узгодження різнорівневих навчальних планів та програм з урахуванням запитів суспільства та потреб ринку праці.

Побудова педагогічної системи професійної підготовки майбутніх фахівців залізничного транспорту покликана усунути суперечності, що мають місце, між теоретичними основами та практичною їх реалізацією в освітньому процесі.

\section{Література}

1. Александров Г.Н. Педагогические системы, педагогические процессы и педагогические технологии в современном педагогическом знании. Образовательные технологии и общество. 2000. №3(2). С.134-149.

2. Безрукова В.С. Педагогика. Проективная педагогика: учебн. для индустр.-пед. техникумов и для студ. инж.-пед. спец. Екатеринбург: Деловая книга, 1999. 329 с.

3. Беспалько В.П. Основы теории педагогических систем. Воронеж: Изд-во Воронежского ун-та, 1977. 304 с.

4. Гулай O.I. Методичні основи формування фундаментальної складової професійної компетентності фахівців будівельного профілю: монографія / за наук. ред. докт. пед. наук, проф. Л.М. Романишиної. Луцьк : РВВ ЛНТУ, 2013. 296 с.

5. Дмитренко Т.О., Яресько К.В. Критеріальні характеристики педагогічної системи як підгрунтя розробки технології дослідження складного об'єкта. Вісник 
Луганського нач. ун-ту ім. Т. Шевченка. 2011. № 21 (232), ч. II. C. 84-90.

6. Сжова О.В. Класифікація моделей в педагогічних дослідженнях. Наукові записки. Серія: Проблеми методики фізико-математичної та технологічної освіти. Том 2. №5. 2014. C.202-207.

7. Жижко Т.А. Педагогічна система один із чинників впровадження ідеї інтенсифікації у професійній підготовці майбутніх фахівців. Науковий часопис НПУ імені М. П. Драгоманова. Серія 11. Соціологія. Сочіальна робота. Соціальна педагогіка. Управління. 2005. Вип. 3. С.144-151.
8. Заболоцкий В.П.,
Оводенко А.А,
Степанов А.Г. Математическое моделирование в управлении. СанктПетербург : СПб ГУАП, 2001. 196 с.

9. Зобнин Б.Б. Моделирование систем: конспект лекций. Екатеринбург: Изд-во УГГГА, 2001. 129 с.

10. Кузьмина Н.В. Предмет акмеологии [2-е изд., испр. и доп.]. Санкт-Петербург : Политехника, 2002. 189 с.

11. Кузьмінський А.І. Педагогіка у запитаннях і відповідях: навч. посібн. Київ : Знання, 2006. 311 с.

12. Ничкало Н.Г. Професійно-технічній освіті - державну політику та науково-педагогічне забезпечення. Нові технології навчання: наук.-метод. зб. Вип. 15. Київ: ІСДО, 1995. C. 9-18.

13. Оршанський Л.В. Професійна педагогіка: навч. посібн. для студентів спеціальності «Професійне навчання». Київ, 2006. $360 \mathrm{c}$.

14. Побірченко Н.С. Формування неперервної педагогічної освіти як системи з погляду історичних перетворень (II половина XIX - початок XX ст.). Педагогіка і психологія. 2010. № 2 (67). C. 68-78.

15. Штофф В.А. Моделирование в философии. Ленинград: Наука, 1966. 302 с. 


\section{Маланюк Н. М.}

\section{Система професійної підготовки майбутніх фахівців залізничного транспорту в умовах неперервної освіти}

\section{Анотація \\ У представленій публікації здійснена спроба} обгрунтувати систему професійної підготовки майбутніх фахівців залізничного транспорту в умовах неперервної освіти як єдність таких блоків: цільового, змістового, операційного та результативного. Проаналізовано складові кожного блоку, а також взаємозв'язки між ними. Розкрито сутність та здійснено аналіз ключових характеристик дефініції «педагогічна система». Професійна підготовка майбутніх фахівців залізничного транспорту повинна відповідати запитам суспільства, а також відображати рівень розвитку науки і техніки. Майбутні фахівці залізничного транспорту повинні володіти професійною компетентністю, яка $\epsilon$ вирішальною якістю фахівця в умовах євроінтеграційних процесів, мобільності ринку праці та зростаючих вимог від роботодавців.

Системотворчим фактором $\epsilon$ мета - формування професійної компетентності майбутніх фахівців залізничного транспорту в системі «коледж-університет».

Побудова авторської системи професійної підготовки майбутніх фахівців залізничного транспорту повинна $\epsilon$ спробою вдосконалення традиційної системи професійної освіти. Така система повинна базуватися на гуманістичних засадах, за яких кожна особистість є найбільшою цінністю разом $з$ іiі індивідуальними особливостями, задатками та здібностями. Ключовими методологічними підходами системи професійної підготовки майбутніх фахівців залізничного транспорту мають стати особистісноорієнтований, діяльнісний та компетентнісний. Ключовими принципами побудови системи є наступності, професійної 
спрямованості, системності та послідовності, неперервності освіти, «освіта для майбутнього».

Для дослідження системи професійної підготовки майбутніх фахівців залізничного транспорту побудована структурно-функціональна модель такої системи, яка відображає функціональні зв'язки між структурними компонентами системи. Розробка моделі дає змогу здійснювати пошук шляхів вдосконалення системи професійної підготовки майбутніх фахівців даного напрямку. Впровадження системи професійної підготовки майбутніх фахівців залізничного транспорту в освітній процес сприятиме підвищенню ефективності процесу підготовки майбутніх фахівців на різних етапах ступеневої освіти.

Ключові слова: структурно-функціональна модель, професійна освіта, система професійної підготовки, неперервна освіта, фахівці залізничного транспорту.

\section{Маланюк Н. М.}

\section{Система профессиональной подготовки будущих специалистов железнодорожного транспорта в условиях непрерывного образования}

\section{Аннотация}

В представленной публикации осуществлена попытка обосновать систему профессиональной подготовки будущих специалистов железнодорожного транспорта в условиях непрерывного образования как единство следующих блоков: целевого, содержательного, операционного и результативного. Проанализированы составляющие каждого блока, а также взаимосвязи между ними. Раскрыта сущность и осуществлен анализ ключевых характеристик дефиниции «педагогическая система». Профессиональная подготовка будущих специалистов железнодорожного транспорта должна отвечать запросам общества, а также отражать 
уровень развития науки и техники. Будущие специалисты железнодорожного транспорта должны обладать профессиональной компетентностью, которая является решающей качеством специалиста в условиях интеграционных процессов, мобильности рынка труда и растущих требований от работодателей.

Системообразующим фактором является цель формирование профессиональной компетентности будущих специалистов железнодорожного транспорта в системе «колледж-университет».

Построение авторской системы профессиональной подготовки будущих специалистов железнодорожного транспорта должна является попыткой совершенствования традиционной системы профессионального образования. Такая система должна базироваться на гуманистических принципах, при которых каждая личность является наибольшей ценностью вместе с его индивидуальными особенностями, задатками и способностями. Ключевыми методологическими подходами системы профессиональной подготовки будущих специалистов железнодорожного транспорта должны стать личностно-ориентированный, деятельностный и компетентностный. Ключевыми принципами построения системы является преемственности, профессиональной направленности, системности и последовательности, непрерывности образования, «образование для будущего».

Для исследования системы профессиональной подготовки будущих специалистов железнодорожного транспорта построена структурно-функциональная модель такой системы, которая отражает функциональные связи между структурными компонентами системы. Разработка модели позволяет осуществлять поиск путей совершенствования системы профессиональной подготовки будущих специалистов данного направления. Внедрение системы профессиональной подготовки будущих 
специалистов железнодорожного транспорта в образовательный процесс будет способствовать повышению эффективности процесса подготовки будущих специалистов на разных этапах многоуровневого образования.

Ключевые слова: структурно-функциональная модель, профессиональное образование, система профессиональной подготовки, непрерывное образование, специалисты железнодорожного транспорта. 